of hypoxia and glutamine or glucose deprivation. Endocr. Reg. 2013. 47 (1): 15-26.

2. Minchenko D.O., Kharkova A.P., Karbovskyi L.L., Minchenko O.H. Expression of insulin-like growth factor binding protein genes and its hypoxic regulation in U87 glioma cells depends on ERN1 mediated signaling pathway of endoplasmic reticulum stress. Endocr. Reg. 2015. № 49 (2): 73-83.

3. Minchenko D.O., Kharkova A.P., Halkin O.V., Karbovskyi L.L., Minchenko O.H. Effect of hypoxia on the expression of genes encoded insulin-like growth factors and some related proteins in U87 glioma cells without IRE1 function. Endocr. Reg. 2016. 50 (2): 43-54.

4. Minchenko D.O., Tsymbal D.O., Luzina O.Y., Riabovol O.O., Danilovskyi SV, Minchenko O.H. Silencing of NAMPT leads to upregulation of insulin receptor substrate 1 gene expression in U87 glioma cells. Endocr. Reg. 2020.54 (1): 31-42.

5. Minchenko D.O., Khita O.O., Tsymbal D.O., Danilovskyi S.V., Rudnytska O.V., Halkin O.V., Kryvdiuk I.V., Smeshkova M.V., Yakymchuk M.M., Bezrodnyi BH, Minchenko O.H. Expression of IDE and PITRM1 genes in IRE1 knockdown U87 glioma cells: effect of hypoxia and glucose deprivation. Endocr. Reg. 2020.54 (3): 183-195.

DOI https://doi.org/10.30525/978-9934-26-047-6-36

\title{
СУЧАСНИЙ ПЕРЕБІГ ЕНТЕРОВІРУСНОӤ ІНФЕКЦІЇ У ДІТЕЙ
}

\section{Онофрійчук О. С.}

кандидат медичних наук,

дочент кафедри дитячих інфекиійних хвороб

Вінницький національний медичний університет імені М. I. Пирогова

Гончарук А. М.

асистент кафедри дитячих інфекиійних хвороб

Вінницький національний медичний університет імені М. І. Пирогова м. Вінниця, Украӥна

В останні роки намітилася чітка тенденція активації ентеровірусної інфекції в світі, про що свідчать постійно зареєстровані в різних країнах світу епідеміологічні підйоми захворюваності й спалахи [1]. 3 одного боку, це пов'язано із зменшенням рівня захворюваності 
раніше розповсюджених хвороб, утворилася так звана «ніша», що заповнюється іншими, раніше менш актуальними інфекціями. 3 іншого боку, звичайно, поява і впровадження в практику сучасних методів діагностики дозволяють краще виявляти різноманітні «нові» інфекційні чинники $[1,2]$.

Ентеровірусні інфекції - це велика група гострих інфекційних захворювань, які характеризуються лихоманкою та поліморфізмом клінічних симптомів, обумовлених враженням центральної нервової та серцево-судинної систем, шлунково-кишкового тракту, м'язової системи, легень, печінки, нирок та інших органів $[1,2,3]$.

Процес виявлення та ідентифікації нових ентеровірусів триває. Відповідно до останньої класифікації вірусів, прийнятої Міжнародним комітетом з таксономії вірусів у 2005 р. в Парижі та у 2006 р. у СанФранциско, яка грунтується на молекулярно-біологічних властивостях вірусів, виділено 5 видів (поліовіруси та ентеровіруси людини А, В, C, D), які належать до роду Enterovirus, родини Picornaviridae [1]. Вони відрізняються рецепторами, які забезпечують проникнення в клітинумішень, імунною відповіддю хазяїна та - спектром асоційованих 3 ними клінічних проявів. Найбільш поширені ЕСНО, Коксакі А (71), В (69), Д (70), періодичність спалахів, яких кожні 3 - 4 роки.

Згідно даних ВОО3, щорічно реєструються близько 75 \% випадків ентеровірусної інфекції, які припадають на дітей молодших 15 років. Діти першого року життя хворіють в кілька разів частіше, ніж старші діти. Для захворювання характерна літньо-осіння сезонність. Основним механізмом передачі $\epsilon$ - фекально-оральний, проте слід відмітити, що можливий і повітряно-краплинний та контактно-побутовий шляхи [2].

Офіційна реєстрація ентеровірусної інфекції в нашій країні не ведеться, але на підставі регіональної реєстрації хворих, які надходили до лікарень м. Вінниці, необхідно зазначити, що останні чотири роки спостерігається збільшення захворюваності на дану інфекцію серед населення Вінницької області, особливо дітей. Проаналізувавши статистичні дані по обласній клінічній дитячій інфекційній лікарні (ОДКІЛ) м. Вінниці, слід зауважити, що за останні 10 років спостерігається підйом захворюваності на ентеровірусну інфекцію.

Так, в період із 2010 - по 2020 рр. нами проаналізовано 197 випадків захворювання на ентеровірусну інфекцію, що знаходились у ОКДІЛ м. Вінниці на стаціонарному лікуванні. У 2010 році по ВОКДІЛ було діагностовано 2 випадки ентеровірусної інфекції, у 2011 та 2012 роках - 1 та 2 випадки, відповідно. Починаючи із 2013 року кількість хворих збільшилась до 8 дітей та 6-ти у 2014 році. У 2015 та 
2016 рр. - 12 та 13 хворих, відповідно, у 2017 році - дану інфекцію виявлено у 70 хворих. Протягом 2018 р. проліковано 24 дитини, у 2019 p. - 49 хворих, у 2020 р. - 11 пацієнтів. Вікова медіана даних пацієнтів склала 5,6 роки. Гендерний склад: 115 хлопчиків $(58,37$ \%) та 82 дівчинки (41,63\%).

Спостерігалась характерна літньо-осіння сезонність даної інфекції із переважним високим показником у липні-жовтні - 168 хворих $(85,2 \%)$. Всі діти мали спорадичну захворюваність, ніхто із них не надійшов із вогнища інфекції.

У нашому дослідженні було виділено такі основні клінічні форми: серозний менінгіт у 13 дітей $(6,6 \%)$, ентеровірусний везикулярний стоматит із екзантемою - у 153 хворих (77,6 \%), ентеровірусний везикулярний фарингіт (герпангіна) - у 31 пацієнта (15,8 \%).

Клінічні форми ентеровірусної інфекції діагностовано на основі типових клінічних та епідеміологічних даних, результатів загальноприйнятих лабораторних досліджень, а також серологічних досліджень та молекулярно-генетичного аналізу (ПЛР).

Особливістю перебігу ентеровірусних менінгітів $\epsilon$ виявлення у більш ніж половини хворих (53,8 \%) комбінованих форм інфекції 3 залученням в процес інших органів і систем, що співпадає із даними інших дослідників $[4,6,7]$. Усі хворі мали гострий початок захворювання, 3 вираженою гіпертермією до $39-40^{\circ} \mathrm{C}$ та інтоксикаційним синдромом. Симптоми ураження оболонок мозку з'являлися на 1-3 день у 30,8 \% хворих, в решти - на 5-7 день захворювання. Перебіг ентеровірусних менінгітів мав характерний хвилеподібний перебіг із значними коливаннями добової температури та нестійкими менінгіальними знаками, а саме Керніга та Брудзинського. У 3 хворих (23 \%) 3 менінгітом серед клінічних симптомів мав місце лише інтенсивний головний біль та блювання. Діагностика ускладнювалась частим переважанням у перші дві доби захворювання нейтрофільного плейоцитозу, який потім змінювався на лімфоцитарний при дослідженні спинно-мозкової рідини. В гемограмі спостерігалась лейкопенія лише у 5 хворих (38,4 \%), а у решти відмічався помірний лейкоцитоз. Перебіг серозних менінгітів, як правило, доброякісний, санація ліквору відбувалася наприкінці третього тижня захворювання.

Значно частіше (153 хворих, 77,6 \%) спостерігалася везикулярна висипка 3 локалізацією на пальцях і долонях кистей та стоп, іноді сідницях. У більшості пацієнтів $(78,4$ \%) наявність екзантеми поєднувалась 3 появою енантеми у вигляді герпангіни та збільшенням шийних лімфатичних вузлів («Hand, Foot and Mouth Disease» - 
«хвороба руки - ноги - рот»). Даний синдром найчастіше пов'язаний 3 інфікуванням вірусами Коксакі А 10, А 16 та ентеровірусом 71 [7, 8].

Всі діти із ентеровірусним везикулярним стоматитом із синдромом екзантеми мали легкий (у 77,1 \%) та середньоважкий перебіг (22,9 \%). Варто зазначити, що у 15 хворих $(9,8$ \%) спостерігалось проксимальне відшарування нігтьового ложа із подальшою десквамацією нігтьової пластинки.

Ентеровірусний везикулярний фарингіт часто дебютував у дітей віком від $3-6$ років. При поступленні у стаціонар хворі скаржились на підвищення температури тіла (86,4 \%), біль у горлі, особливо під час ковтання (93,4\%). При обстеженні у всіх хворих мав місце помірно виражений інтоксикаційний синдром та зміни в ротоглотці. Патогномонічним симптомом герпангіни у всіх хворих були наявні на мигдаликах, м'якому піднебінні, язичку, задній стінці глотки поодинокі дрібні везикули та виразки. Перебіг такої клінічної форми мав благоприємний прогноз.

Всі хворі із різноманітними клінічними формами ентеровірусної інфекції мали доброякісний перебіг, ускладнень не спостерігалось.

Висновки. Ентеровірусна інфекція досить часто зустрічається серед дитячого населення і перебігає у вигляді різноманітних клінічних форм: ентеровірусні серозні менінгіти, герпангіни та ентеровірусний везикулярний стоматит із синдромом екзантеми. Особливості перебігу даного захворювання утруднюють діагностику та лікування.

\section{Література:}

1. Doan SI, Savchuk AI, Haydey VR. Epidemic situation and improvement of epidemiological surveillance for enterovirus infections. Problemy vijs'kovoi' ohorony zdorov'ja . 2015;44(2):91-94. (in Ukrainian).

2. Lytvyn GO, Homyn ОЈа. Литвин Г. O. Features of the course of enterovirus infection in the Lviv region during 2015. ScienceRise. Medical Science. 2016;5:19-24. (in Ukrainian).

3. Abzug MJ. The enteroviruses: problems in need of treatments. J Infect. 2014 Jan;68 Suppl 1:S108-14. doi: 10.1016/j. jinf.2013.09.020

4. Rhoades RE, Tabor-Godwin JM, Tsueng G, Feuer R. Enterovirus infections of the central nervous system. Virology. 2011 Mar 15;411(2): 288-305. doi: 10.1016/j.virol.2010.12.014.

5. Michos AG, Syriopoulou VP, Hadjichristodoulou C, et al. Aseptic meningitis in children: analysis of 506 cases. PLoS One. 2007 Aug 1;2(7):e674. doi: 10.1371/journal.pone.0000674. 
6. Shaker OG, Abdelhamid N. Detection of enteroviruses in pediatric patients with aseptic meningitis. Clin Neurol Neurosurg. 2015 Feb;129: 67-71. doi: 10.1016/j.clineuro.2014.12.004.

7. Yogarajah T, Ong KC, Perera D, Wong KT. Enterovirus A71 and coxsackievirus A16 show different replication kinetics in human neuronal and non-neuronal cell lines. Arch Virol. 2017 Mar;162(3):727-737. doi: 10.1007/s00705-016-3157-4.

8. Luo KW, Gao LD, Hu SX, et al. Hand, Foot, and Mouth Disease in Hunan Province, China, 2009-2014: Epidemiology and Death Risk Factors. PLoS One. 2016 Nov 29;11(11):e0167269. doi: 10.1371/ journal.pone.0167269.

DOI https://doi.org/10.30525/978-9934-26-047-6-37

\title{
THE MARGINAL NUCLEUS OF THE POSTERIOR HORNS OF THE SPINAL CORD OF EMBRYOS AND HUMAN FETUSES
}

\author{
Prykhodko S. O. \\ Assistant at the Department of Human Anatomy \\ National Pirogov Memorial Medical University, Vinnytsya \\ Vinnytsia, Ukraine \\ Shkolnikov V.S. \\ Doctor of Medical Sciences, \\ Professor at the Department of Human Anatomy \\ National Pirogov Memorial Medical University, Vinnytsya \\ Vinnytsia, Ukraine
}

The development and formation of human organs and systems will always remain a priority for scientists. Understanding the mechanisms of these processes is the basis of normal and comfortable life in the future. Also, it will provide an opportunity to control and correct organogenesis in the intrauterine period of ontogeny.

In particular, pre- and perinatal lesions of internal organs and structures of the central nervous system in children are one of the most pressing medical and social problems of modern neurology and pediatrics, due to both high mortality of young children and a significant proportion of this pathology in infant mortality or disability [1, p. 50].

There is a sufficient number of scientific reports in the available literature, which would concern studies of the central nervous system, in 